\title{
MODEL PELAYANAN PENDIDIKAN INKLUSI DI MADRASAH: STUDI KASUS DI MADRASAH IBTIDAIYAH IBTIDAUL FALAH DAWE-KUDUS
}

\section{Sulthon}

IAIN Kudus, Jawa Tengah, Indonesia

Email: Sulthon52@gmail.com

\begin{abstract}
ABSTRAK
Pendidikan inklusi sebagai layanan pendidikan yang menerima anak disabilitas bersama dengan anak normal di sekolah biasa dalam perjalannya masih banyak mengalami hambatan, baik terkait dengan kekurang siapanya guru, sekolah,dan masyarakat. Dalam rangka memberikan layanan pendidikan yang merata dan adil bagi anak disabilitas, maka perlu dipikirkan untuk membangun pendidikan inklusi di madrasah. Untuk itu dilakukan penelitian yang bertujuan untuk melihat bagaimana pelaksanaan inklusi di madrasah dan bagaimana model pendidikan inklusi di madrasah. Penelitian ini menggunakan metode kualitatif dengan pendekatan fenomenologi. Hasil penelitian menunjukkan bahwa: 1) madrasah ini telah melaksanakan pembelajaran inklusi bagi siswa disabilitas, karena secara legal formal belum memiliki ijin operasional dari Dinas Pendidikan ataupun dari Kementerian Agama, maka dikatakan sebagai rintisan madrasah inklusi; 2) Model madrasah inklusi ini menggunakan model "pullout" yaitu anak disabilitas belajar bersama temannya di kelas regular dalam kelompok khusus, dan dalam waktu-waktu tertentu ditarik dari kelas regular ke ruang sumber untuk belajar dengan guru pembimbing khusus. Hal ini didasarkan pada pertimbangan: 1) anak disabilitas di madrasah ini termasuk anak lambat belajar; 2) memiliki kesulitan dalam belajar pada mata pelajaran tertentu sehingga perlu penanganan pembimbing khusus; 3) pada pelajaran yang lainnya anak disabilitas ini masih bisa selesai pada kelas biasa.
\end{abstract}

Kata Kunci: Pendidikan Inklusi, Disabilitas, Madrasah Ibtidaiyah.

AL-BIDAYAH: Jurnal Pendidikan Dasar Islam

Volume 10, Nomor 02, Desember 2018; P-ISSN: 2085-0034, E-ISSN: 2549-3388 


\begin{abstract}
Inclusion education as an education service that accepts children with disabilities together with normal children in regular school on the activity there are still many problems both related to the lack of preparedness of teachers, schools and communities. In order to provide equitable and fair education services for children with disabilities, it is necessary to think about building inclusive education in madrasas. The research was carried out which aims to see how the inclusion in madrasas is implemented and how the model of inclusive education in madrasas. This study uses qualitative methods with a phenomenological approach. The results show that: 1) This madrasah has carried out inclusive learning for students with disabilities, because legally there is no operational permit from the Education Office or from the Ministry of Religion, it is said to be a pilot for inclusion madrasas; 2) This inclusion madrasah model uses a "pullout" model that is, children with disabilities learn with their friends in regular classes in special groups, and at certain times are drawn from the regular class to the source room to study with special teachers. This is based on consideration; (1) children with disabilities in this madrasah include children who are slow to learn; (2) have difficulties in learning in certain subjects so that it needs to be handled by a special supervisor; (3) in the other lessons, children with disabilities can still be completed in the regular class.
\end{abstract}

\title{
Keywords: $\quad$ Inclussions Education, Disabilities, Islamic Elementary School (MI)
}

\section{A. PENDAHULUAN}

Pendidikan merupakan hak yang dimiliki setiap warga negara tanpa terkecuali, termasuk anak disabilitas atau anak berkebutuhan khusus. ${ }^{1}$ Anak yang mengalami disabilitas baik fisik (tuna netra, tuna rungu, tuna daksa), mental-intelektual (tuna grahita), dan sosial-emosional (tuna sosial atau laras), gangguan komunikasi (autis) juga berhak mendapatkan pendidikan. Pernyataan ini juga diperkuat dengan UndangUndang No.20 tahun 2003 tentang Sistem Pendidikan Nasional, Pasal 5, ayat 2 dan 4 yang berbunyi bahwa: ayat 2 . Warga negara yang memiliki kelainan fisik, emosional,

1. Undang-Undang Dasar 1945 Pasal 31

152 AL-BIDAYAH, Volume 10, Nomor 02, Desember 2018 
mental, intelektual, dan/ atau sosial berhak memperoleh pendidikan khusus; dan ayat 4 . Warga negara yang memiliki potensi kecerdasan dan bakat istimewa berhak memperoleh pendidikan khusus. ${ }^{2}$

Undang-undang di atas menunjukkan bahwa setiap anak yang mengalami disabilitas memiliki hak yang sama untuk memperoleh pendidikan, namun dalam realitasnya masih banyak anak disabilitas yang belum tersentuh pendidikan dengan alasan terbatasnya sekolah untuk anak disabilitas karena tempat yang jauh atau alasan lain sehingga pemerataan pendidikan bagi anak disabilitas masih belum terpenuhi.

Keterbatasan dan kekurangan jumlah sekolah bagi anak disabilitas sangat tidak manusiawi jika tidak segera diatasi. Pendidikan bagi anak disailitas sangat penting dan membantu dalam meningkatkan kemampuan dan kemandirian dalam hidupnya, dengan demikian pendidikan sangat dibutuhkan dalam hidup anak disabilitas. ${ }^{3}$ Dengan demikian tidak terpenuhinya pendikan bagi mereka berarti belum tercapai kemerdekaan dalam hidup dan keadilan bagi anak disabilitas di negeri ini. ${ }^{4}$

Layanan pendidikan bagi anak disabilitas dengan model SLB dan SDLB yang berjalan selama ini masih belum cukup memberikan fasilitas yang memadai bagi anak disabilitas untuk mendapatkan pendidikan. ${ }^{5}$

Tingginya angka jumlah anak disabilitas yang harus dilayani dalam pendidikan dan terbatasnya sekolah khusus yang tersedia, dari 318.600 ABK di Indonesia, 24,7\% atau 78.689 anak yang sudah mengikuti pendidikan formal, artinya masih terdapat sebanyak $65,3 \%$ yang masih belum mendapatkan hak pendidikan, ${ }^{6}$ dengan demikian perlu diupayakan melalui program pendidikan inklusi. Pendidikan inklusi yaitu sistem penyelenggaraan pendidikan yang memberikan kesempatan kepada semua peserta

2. Undang-undang Nomor 20 Tahun 2003

3. Pratiwi JP. 2015. Sekolah Inklusi Untuk Anak Berkebutuhan Khusus: Tanggapan Terhadap Tantangan Kedepannya, Pendidikan Guru Sekolah Dasar, Program Pascasarjana UNS, Prosiding Seminar Nasional Pendidikan: Meretas Sukses Publikasi Ilmiah Bidang Pendidikan Jurnal Bereputasi. Kerja sama Program Studi S-3 Ilmu Pendidikan, Program Studi S-2 Pendidikan Luar Biasa Universitas Sebelas Maret, Surakarta dan ISPI Wilayah Jawa Tengah, Surakarta, 21 November 2015. 978-979-3456-52-2.

4. Haryono, Syaifudin A, and Widiastuti S, "Evaluasi Pendidikan Inklusif Bagi Anak Berkebutuhan Khusus (ABK) Di Provinsi Jawa Tengah," Universitas Negeri Semarang Jurnal Penelitian Pendidikan (2015): hlm. 104.

5. Direktorat Pendidikan Luar Biasa, Direktorat Jenderal Pendidikan Dasar dan Menengah, Departemen Pendidikan Nasional, 2005.

6. Shopyatun AR. and Rasido I., "Pengembangan Bahan Ajar Anak Berkebutuhan Khusus Untuk Pendidikan Inklusi Bagi Mahasiswa Program Studi PG/PAUD FKIP Universitas Tadulako," Tri Sentra Jurnal Ilmu Pendidika, 2013, hlm. 3. 
didik yang memiliki kelainan dan memiliki potensi kecerdasan dan/ bakat istimewa untuk mengikuti pendidikan atau pembelajaran dalam satu lingkungan pendidikan secara bersama-sama dengan peserta didik pada umumnya. ${ }^{7}$ Inklusi sebagai model layanan pendidikan bagi anak disabilitas belajar di kelas khusus bersama dengan pembimbing khusus dan selanjutnya diintegrasikan di kelas biasa sesudah semuanya siap $^{8}$ dan Stubbs S. (2002). ${ }^{9}$

Pendidikan inklusi merupakan pendidikan yang lebih memberikan kesempatan pada semua siswa tanpa memandang perbedaan-perbedaan yang dimiliki seperti, perbedaan fisik, intelektual, kemampuan, kedisabilitasan, dan sebagainya untuk belajar bersama, bekerja sama dalam menggali dan meningkatkan kemampuan dan keterampilan di sekolah yang sama. ${ }^{10}$ Pendidikan inklusi memungkinkan semua peserta didik dapat berpartisipasi penuh dalam berkarya dan meningkatkan kemampuan yang dimiliki seoptimal mungkin dalam satu pendidikan yang sama untuk semua anak.

Program pendidikan inklusi ini, relevan dengan program UNESCO yang telah mencangakan pendidikan untuk semua atau Educational for All yaitu pendidikan adalah milik semua anak tanpa membedakan perbedaan yang dimiliki baik anak normal maupun anak penyandang disabilitas (An Efa Flagship, 2004). ${ }^{11}$ Serta mewujudkan penyelenggaraan pendidikan yang menghargai keanekaragaman, dan tidak diskriminatif bagi semua peserta didik. ${ }^{12}$

Program pendidikan inklusi telah dicanangkan di Indonesia sejak tahun 2009 namun dalam praktiknya tidak berjalan sesuai dengan rencana. Masih banyak sekolah inklusi yang belum berjalan karena banyaknya kendala terkait dengan belum siapnya

7. Permendiknas Nomor 70 tahun 2009 pasal 1.

8. Skjorten, M. 2003. Menuju Inklusi dan Pengayaan, (Online), (http://www.idp-europe. org/indonesia/buku-inklusi-14k, diakses 02 Nopember $2011 \mathrm{hlm} .145$

9. Sue Stubbs, Pendidikan Inklusif (Ketika Hanya Ada Sedikit Sumber) (Bandung: UPI, 2002).

10. Junanto S. Kusna, "Evaluasi Program Pembelajaran Di PAUD Inklusi Dengan Model Context, Input, Process, and Product (CIPP), Journal of Disability Studies" Vol. V No. 2 (July 2018), hlm. 179-194.

11. An Efa Flagship. (2004). The Rights to Education for Persons with Disabilities: towards Inclusion, (Online), (http://unesdoc.unesco.org/education_for_all_ (efa_america)_ inclusion.pdf, diakses 01 Nopember 2011.

12. Amka, "Implementasi Pendidikan Karakter Inklusi Bagi Anak Berkebutuhan Khusus Di Sekolah Reguler," Universitas Lambung Mangkurat Banjarmasin Madrosatuna: Journal of Islamic Elementary School (2017), hlm. 8. 
guru-guru umum atau tidak memiliki pemahaman pendidikan untuk anak disabilitas, dari 519 sekolah yang menyatakan sebagai sekolah inklusi di Jawa Tengah, guruguru masih membutuhkan tambahan pembekalan/ pelatihan pendidikan inklusif, hal ini disebabkan ketidakpahaman guru dalam melaksanakan pendidikan inklusi, ${ }^{13}$ terbatasnya guru khusus, kurikulum inklusi, serta model pelaksanaan pendidikan yang terintegrasi dalam layanan inklusi ${ }^{14}$. Tidak meratanya pendidikan bagi anak disabilitas baik melalui sistem pendidikan eksklusif dalam bentuk SLB maupun SDLB, serta tidak berjalannya program pendidikan inklusi sesuai dengan rencana, maka dapat dikatakan bahwa pemerataan pendidikan bagi anak disabilitas masih menyimpan segudang masalah yang serius.

Kondisi di atas perlu direspon dengan adanya percepatan penyediaan layanan pendidikan bagi anak disabilitas dengan memberdayakan madrasah sebagai bagian dari lembaga yang menangani pendidikan dibawah Kementerian Agama. Madrasah sebagai lembaga yang mempersiapkan generasai dengan memberikan pendidikan yang berbasis keagamaan, juga memiliki tugas yang sama untuk memberikan penddikan bagi anak disabilitas.

Madrasah sebagai lembaga pendidikan yang berlandaskan pada pengembangan keagamaan sangat sesuai untuk anak disabilitas karena melalui penyadaran agama akan menumbuhkan kekuatan penerimaan diri anak disabilitas karena didasarkan pada keimanan dan qodlo qodar Alloh SWT. Dengan demikian melaksanakan pendidikan inklusi di madrasah akan lebih berhasil karena pendekatan agama.

Selama ini belum banyak madrasah yang melaksanakan pendidikan inklusi bagi anak disabilitas, sebagaimana hasil penelitian Sholikhah RM. (2016) bahwa Kementerian Agama belum memiliki aturan dan kebijakan tentang pendidikan inklusi. ${ }^{15}$ Pada penelitian awal ditemukan bahwa di Madrasah Ibtidaiyah (MI) di Dawe Kabupaten Kudus ditemukan banyak anak yang memiliki IQ rendah di bawah rata-rata yang dilayani di MI ini, dalam layanan pendidikan, guru memberikan pelajaran secara umum kemudian bagi anak yang memiliki kemampuan rendah selanjutnya diberikan pembinaan secara khusus dan sering hingga waktu istirahat.

13. Haryono, Syaifudin A, and Widiastuti S, "Evaluasi Pendidikan Inklusif Bagi Anak Berkebutuhan Khusus (ABK) Di Provinsi Jawa Tengah,” hlm. 121.

14. Pratiwi JP. Op.Cit. hlm. 26.

15. Sholikhah RM. 2016, Pendidikan Inklusif di Kementerian Agama (Studi di Madrasah Ibtidaiyah Ma,arif Giriloyo 2 dan Madrasah Ibtidaiyah YAPPI Balong), tesis. tt. Pascasarjana Universitas Islam Negeri Yogyakarta. hlm. 64. 
Sebenarnya ini merupakan praktik madrasah inklusi sehingga penelitian ini bersifat rintisan model inklusi di Madrasah.

Madrasah sebagai lembaga pendidikan yang berlandaskan agama Islam tentunya lebih memiliki kepekaan dan ramah terhadap anak disabilitas karena merupakan ajaran yang ditekankan dalam Islam sebagai amalan sholihan dan wujud rasa pengabdian pada sesama, ${ }^{16}$ karena didasarkan pada Firman Alloh yang artinya sebagai berikut:

"Tidak ada halangan bagi orang buta, tidak pula bagi orang pincang, tidak pula bagi orang sakit, dan tidak pula bagi dirimu sendiri, makan bersamasama mereka di rumah kamu sendiri atau di rumah bapak-bapakmu, di rumah ibu-ibumu, di rumah saudara-saudaramu yang laki-laki, di rumah saudarasaudaramu perempuan, di rumah saudara bapakmu yang laki-laki, di rumah saudara bapakmu yang perempuan, di rumah yang kamu miliki kuncinya, atau di rumah kawan-kawanmu. Tidak ada halangan bagi kamu makan bersamasama mereka atau sendirian. Maka apabila kamu memasuki (suatu rumah dari) rumah-rumah (ini) hendaklah kamu memberi salam kepada (penghuninya yang berarti memberi salam) kepada dirimu sendiri, salam yang ditetapkan dari sisi Allah, yang diberi berkat lagi baik. Demikianlah Allah menjelaskan ayat-ayat (Nya) bagimu, agar kamu memahaminya (Qur'an Surat An-Nur: 61) ${ }^{17}$

Ayat di atas memberikan perintah untuk tidak membeda-bedakan manusia berdasarkan kecacatan dalam berinteraksi atau bergaul dengannya, hal ini sejalan dengan memberikan layanan pendidikan inklusi bagi anak disabilitas bersama dengan anak normal. Dengan demikian madrasah inklusi merupakan anjuran dalam agama Islam tanpa membeda-bedakan anak dari perbedaan individual, karena dalam Islam yang dinilai di sisi Alloh bukan fisiknya tapi Alloh melihat hati dan perbuatannya.

Berdasarkan urian di atas, maka anak disabilitas harus memperoleh pendidikan sesuai dengan kemampuanya bersama teman sebayanya dan di tempat yang tidak jauh dari tempat tinggalnya. Penelitian ini difokuskan pada bagaimana pelaksanaan pendidikan inklusi di Madrasah Ibtidaiyah, Dawe Kudus dan bagaimana model layanan pendidikan inklusi di Madrasah Ibtidaiyah Dawe, Kudus.

16. Mukaffa Z. Taufik and Huda MN., "Pengembangan Model Madrasah Inklusif (Studi Atas Kesiapan Dan Model Pengembangan Kurikulum Madrasah Inklusif Mi AlHidayah, Margorejo Surabaya, Edukasia," UIN Sunan Ampel Surabaya Jurnal Penelitian Pendidikan Islam (2017), hlm. 1.

17. Al-Qur'an dan terjemah. 2008. Surabaya: Duta Ilmu, Surat An-Nur: 61

156 AL-BIDAYAH, Volume 10, Nomor 02, Desember 2018 


\section{B. METODE PENELITIAN}

Metode penelitian yang digunakan dalam penelitian ini adalah deskriptif kualitatif. subyek penelitian adalah kepala sekolah, wakil kepala sekolah, guru kelas dan siswa inklusi. Data tentang pelaksanaan pendidikan inklusi di madrasah menyangkut pembelajaran, pengelolaan pembelajaran antara anak biasa dan anak disabilitas, kemampuan siswa, kurikulum pendidikan dan penanganan masalah belajar bagi anak disabilitas di madrasah. Selain subyek penelitian sebagai sumber primer juga melakukan wawancara dengan informan pendukung yaitu orang tua siswa dan teman siswa inklusi.

Teknik pengumpulan datanya menggunakan teknik wawancara, observasi, dan dokumentasi. wawancara adalah percakapan antara pewawancara (interviewer) yang mengajukan pertanyaan dan orang yang diwawancarai (interviewee) yang memberikan jawaban. ${ }^{18}$ Wawancara dalam penelitian ini dilakukan terhadap kepala madrasah, guru, siswa inklusi dan orang tua, dengan menggunakan wawancara terstruktur, yaitu terlebih dahulu membuat kisi-kisi daftar pertanyaan. Wawancara ini dilakukan sebanyak 2 kali untuk masing-masing guru, siswa inklusi serta satu kali untuk kepala sekolah. Observasi dilakukan di MI Ibtidaul Falah Dawe Kudus Jawa Tengah. Sedang dokumentasi digunakan untuk mengambil data tentang hasil tes inteligensi siswa yang dinyatakan lambat belajar serta informasi yang berkaitan dengan hasil pembelajaran siswa disabilitas.

Analisis data dalam penelitian ini adalah analisis kualitatif dengan menggali data secara interaktif dan terus-menerus hingga tuntas akhirnya datanya sampai jenuh. ${ }^{19}$ Selanjutnya data yang sudah terkumpul lalu dianalisis melalui tiga (3) tahap yaitu tahap reduksi data, display data dan verifikasi.

\section{Model Pendidikan Inklusi di Madrasah}

Pendidikan inklusi sebagai sistem layanan pendidikan yang mempersyaratkan agar semua anak disabilitas dapat dilayani di sekolah-sekolah terdekat, di kelas regular bersama-sama teman seusianya. ${ }^{20}$

Pendidikan inklusi merupakan layanan pendidikan yang lebih humanis dan demokratis karena memberikan kesempatan pada keragaman anak tanpa membeda-

18. Sugiyono, Metode Penelitian Pendidikan (Bandung: Alfabeta, 2009), hlm. 270.

19. Sugiyono, Metode Penelitian Pendidikan (Bandung: Alfabeta, 2012), hlm. 194.

20. O'Neil, J., Can inclusion Work a Conversation With James Kauffman and Mara SaponShevin (Educational Leadership, 1994/1995). 52(4) hlm. 7-11. 
bedakan kecacatan dengan yang normal. Pendidikan inklusi sebagai bagian dari upaya untuk menuntaskan wajib belajar bagi anak disabilitas yang tidak pernah kunjung selesai dalam usaha pemerataan pendidikan melalui program segregasi atau sistem terpisah (SLB/SDLB). ${ }^{21}$

Pendidikan inklusi sebagai sistem pendidikan yang memberikan layanan dengan berbagai jenis perbedaan individual merupakan hal yang tidak mudah dilakukan manakala tidak ada kesepahaman dan kesamaan visi dalam melaksanakan program pendidikan inklusi. Ketidak berhasilan dalam layanan inklusi selama ini lebih banyak disebabkan karena kurang siapnya sekolah dan guru di sekolah biasa, dengan demikian sebagai salah satu upaya pemberian layanan pendidikan bagi anak disabilitas, maka respon dan kepedulian dari berbagai pihak untuk menuntaskan masalah pendidikan disabilitas ini sangat dibutuhkan salah satunya adalah madrasah sebagai lembaga yang juga menangani pendidikan bangsa yang sudah diakui keberadannya serta keberhasilannya ${ }^{22}$

Pendidikan inklusi di madrasah perlu dilakukan agar pemerataan pendidikan bagi anak disabilitas segera terwujud. Madrasah inklusi memiliki kelebihan dibanding inklusi di sekolah biasa karena madrasah sebagai bagian dari lembaga pendidikan yang lebih menghargai dan memberikan kesempatan pada siswa dengan didasarkan pada pengabdian diri pada Alloh SWT. Anak disabilitas dengan belajar di madrasah selain merasa menyatu dengan teman sebayanya juga mendorong perkembangan keterampilan sosialnya. Denga belajar di madrasah, anak disabilitas akan terbangun persepsi diri dan konsep diri yang positif karena bertambahnya keimanan pada diri anak. Dengan kekuatan iman yang dimiliki akan meningkatkan penerimaan dirinya lebih baik. Semua yang dialami dalam hidupnya semata-mata karena ketentuan Alloh yang harus diterima secara ikhlas. ${ }^{23}$

Kekuatan iman inilah yang mampu membangun solidaritas dan kepekaan diri sehingga rasa menghargai dan toleransi antar siswa dibangun oleh kekuatan hati nurani atau super ego bukan ego yang selalu menerima individu lain berdasarkan

21. Abdurrahman M, Landasan Pendidikan Inklusi dan Implikasinya dalam Penyelenggaraan LPTK, Makalah dalam Pelatihan Buku Ajar Bagi Dosen Jurusan PLB (Yogyakarta, 2002), 26 Agustus, 2002.

22. Anjarsari A. D. and Sulthoni M. E., Penyelenggaraan Pendidikan Inklusi Pada Jenjang SD, SMP, Dan SMA Di Kabupaten Sidoarjo, FIP, Pendidikan Luar Biasa (Universitas Negeri Malang, 2015).

23. Hasan bin Ali Al-Hijazy, Manhaj Tarbiyah Ibnu Qoyyim (Jakarta: Pustaka Al-Kautsar, 2001), hlm. 112-113. 
pada kesamaan kepentingan dan derajat sehingga selalu membedakan orang dari kecacatan yang dialaminya atau karena berbeda dengan yang lain. ${ }^{24}$

Madrasah memiliki potensi untuk menguatkan nilai-nilai keimanan pada siswa dibanding di sekolah umum, karena di madrasah muatan kurikulum agamanya lebih banyak dan pengembangan karakter keagamaan lebih ditekankan. Melalui pengetahuan agama yang baik akan dibangun pengamalan atau praktik agama yang baik pula, dengan praktik agama akan menumbuhkan pengalaman agama sebagai kekuatan untuk selalu menjalankan agama sesuai dengan ajaran agama, dari sinilah akan terbangun kesadaran beragama. ${ }^{25}$ Kesadaran agama akan menumbuhkan kepasrahan dan ketundukan pada ketentuan Alloh termasuk kondisi yang dialaminya adalah takdir yang harus diterima dengan iman.

Penyadaran agama bagi siswa menjadi kunci utama pendidikan di madrasah, karena madrasah dibangun dari misi untuk mendidik generasi berdasarkan pada ajaran agama Islam agar siswa menjadi insan yang beriman dan berakhlakul karimah. Dengan akhlak yang baik ini akan menumbuhkan sikap dan perilaku yang tidak memandang seseorang dari sisi penampilan fisiknya namun lebih memandang aspek kemanusiaanya. Dengan demikian madarasah lebih bisa memahami dan menerima keragaman siswa disabilitas dengan menumbuhkembangkan keimanan dan amal sholeh.

Secara empiris sebenarnya madrasah dari awal sudah menerapkan keragaman siswa dalam belajar, yaitu menerima siswa disabilitas untuk dididik dalam kelas biasa namun sifatnya hanya memberi bantuan pada mereka agar bisa sekolah tanpa memberi label sekolah inklusi.

Pendidikan inklusi memiliki Karakter atau ciri-ciri yaitu, 1) pendidkan inklusi sebagai salah satu upaya untuk menemukan pola pendidikan yang memadukan anak disabilitas bersama dengan anak normal; 2) pendidikan inklusi membangun paradigma pendidikan yang menyamakan anak disabilitas dari eksklusif menjadi inklusif; 3) pendidikan inklusi mengusahakan agar anak yang mengalami disabilitas dapat belajar bersama dengan temannya yang normal, bermain bersama, disekolah yang sama sehingga terbangun interaksi sosial yang saling menghargai sebagai

24. Soma S. and Hajaruddin, Menanggulangi Remaja Kriminal Islam Sebagai Alternatif (Bandung: Nuansa, 2000), hlm. 67.

25. Ancok Dj. and Suroso F.N., Psikologi Islami (Yogyakarta: Pustaka Pelajar, 1994), hlm. 77-74. 
pengalaman yang berguna dalam hidup anak disabilitas; dan 4) pendidikan inklusi dipersiapkan bagi anak disabilitas yang membutuhkan layanan pendidikan khusus. ${ }^{26}$

Dari ciri-ciri di atas, maka madrasah sesungguhnya sudah mempraktikkan program pendidikan inklusi. Sehingga diperlukan adanya labelisasi sebagai lembaga legal formal untuk madrasah inklusi agar pemerataan pendidikan bagi anak disabilitas segera terwujud.

Selama ini penyelenggaraan pendidikan bagi anak disabilitas melalui program segregasi baik dalam bentuk SLB maupun SDLB tidak segera bisa menjangkau sampai kepelosok daerah sehingga pendidikan model ini hanya mampu menampung anak disabilitas di kota-kota besar.

Berdasarkan fakta empiris, pendidikan segregasi hanya melanggengkan kebijakan yang bersifat pragmatis tanpa diimbangi dengan berbagai pertimbangan untung ruginya bagi kepentingan peserta didik. Anak disabilitas membutuhkan layanan pendidikan yang mampu mengembangkan seluruh potensinya tanpa sekatsekat sosial yang mempertajam dirinya dengan masyarakat. selama mereka berada terpisah dalam pendidikan, maka selama itu pula mereka akan tetap jadi manusia yang lain, berbeda, dan hanya merasa punya satu komunitas yang sama dengan dirinya. Dengan kata lain, pendidikan baginya belum berarti memberikan kebebasan untuk berkembangnya seluruh potensi peserta didik.

Dalam konteks pendidikan, pendekatan inklusi dalam praktiknya lebih memberikan peluang bagi anak disabilitas untuk memahami, menyadari diri dan mengembangkan potensi yang dimilikinya dengan penuh kebebasan dan kreativitas dalam atmosfir pendidikan biasa.

Dalam memberikan layanan pendidikan bagi anak disabilitas setidaknya ada dua hal yang segera diupayakan, pertama, masalah pemerataan, dari tahun ke tahun pendidikan bagi anak disabilitas selalu mengalami hambatan pemerataan, masih banyak anak disabilitas yang belum menjangkau pendidikan karena alasan tempat yang jauh. Oleh karena itu program pendidikan inklusi sebagai salah satu alternatif. Kedua, masalah psikologis, pendidikan segregasi melanggengkan rasa senasib sehingga rasa sosialnya menjadi tidak berkembang, oleh sebab itu dengan program inklusi mendorong terbentuknya kesamaan dan kesetaraan sehingga terbangun rasa

26. Direktorat Pendidikan Luar Biasa, Pedoman Penyelenggaraan Pendidikan Terpadu (Jakarta: Dirjen Didakmen, 2004). 
solidaritas dan kepekaan sosial sesama teman yang akhirnya akan membangun konsep diri dan penerimaan diri anak disabilitas menjadi lebih positif.

Dari kedua hal di atas ditemukan bahwa madrasah adalah salah satu lembaga yang sangat efektif untuk upaya pemerataan pendidikan dan membangun sikap dan keterampilan sosial bagi anak disabilitas. Dalam hal pemerataan, terbukti madrasah tumbuh subur justru di daerah pedesaan sehingga terjangkau oleh anak disabilitas. Sedang berkaitan dengan memupuk sikap dan keterampilan sosial didasarkan pada kenyataan bahwa madarasah lebih menyiapkan peserta didik menjadi lebih agamis dengan penanaman nilai-nilai tauhid, ibadah, dan akhlak. Ketiga ajaran ini yang akan membangun keimanan dan akhlak sehingga anak disabilitas akan lebih berkembang keterampilan sosialnya.

Pelaksanaan pendidikan di madrasah dapat menggunakan model pendidikan inklusi dengan berbagai cara sebagai berikut:

1. Inklusi penuh (kelas regular), yaitu anak disabilitas belajar bersama anak lainya (normal) sepanjang hari di kelas regular dengan kurikulum yang sama;

2. Kelas regular dengan cluster, yaitu anak disabilitas belajar bersama anak normal di kelas regular dalam kelompok khusus;

3. Kelas regular dengan pull out, yaitu anak disabilitas belajar bersama anak normal di kelas regular dalam kelompok khusus, dan dalam waktu-waktu tertentu ditarik dari kelas regular ke ruang sumber untuk belajar dengan guru pembimbing khusus;

4. Kelas khusus dengan berbagai pengintegrasian, yaitu anak disabilitas belajar di dalam kelas khusus pada sekolah regular, namun dalam bidang tertentu dapat belajar bersama anak lain (normal) di kelas regular;

5. Kelas khusus penuh, yaitu anak disabilitas belajar di dalam kelas khusus pada sekolah regular. ${ }^{27}$

Setiap sekolah inklusi dapat memilih model-model mana yang akan diterapkan, terutama bergantung kepada: (1) jumlah anak disabilitas yang akan dilayani; (2) jenis kelainan masing-masing anak; (3) gradasi (tingkat) kelainan anak; (4) ketersediaan dan kesiapan tenaga kependidikan; dan (5) sarana dan prasarana yang tersedia.

27. Ibid. 


\section{HASIL PENELITIAN DAN PEMBAHASAN}

Berdasarkan data yang diperoleh dari informan di madrasah yaitu kepala madrasah, guru kelas yang menangani anak disabilitas, wakil ketua bidang kurikulum, siswa inklusi, dan teman siswa normal, selanjutnya dapat di sajikan dalam tabel berikut:

\begin{tabular}{|c|c|c|}
\hline NO. & $\begin{array}{l}\text { INFORMAN/ } \\
\text { JABATAN }\end{array}$ & PELAKSANAAN INKLUSI \\
\hline 1. & NS/ Kepala madrasah & $\begin{array}{l}\text { Bagaimana prosesnya madrasah ini akhirnya menangani } \\
\text { anak disabilitas? } \\
\text { Anak-anak disini banyak yang memiliki kemampuan } \\
\text { di bawah rata-rata berdasarkan hasil tes inteligensi. } \\
\text { Anak anak yang memiliki IQ rendah sering tidak naik } \\
\text { kelas. Dan orang tua ketika disarankan masuk SLB } \\
\text { mereka bilang biar sekolah di madrasah aja bu biar } \\
\text { bisa baca Qur'an, bisa agama bu (SM, Wawancara, } \\
23 \text { Agustus 2018). } \\
\text { Apa kekhususan Siswa disabilitas yang ditangani di } \\
\text { Madrasah ini: } \\
\text { Rata-rata anak yang memiliki kemampuan di bawah } \\
\text { rata-rata, yaitu kategori anak lambat belajar bahkan } \\
\text { ada yang tuna grahita. Anak ini selalu mengalami } \\
\text { kesulitan belajar dan sering tidak naik kelas. } \\
\text { Anak ini tetap ditangani di madrasah ini dengan } \\
\text { sistem pembelajaran klasikal yang dilanjutkan } \\
\text { dengan bimbingan khusus dengan guru khusus. } \\
\text { Ada di setiap kelas anak yang seperti ini dan ditangani } \\
\text { tersendiri dengan model inklusi. } \\
\text { Ada berapa anak di madrasah ini yang memiliki } \\
\text { kemampuan rendah? } \\
\text { Anak yang kategori ini di madrasah kami ada } 12 \text { anak } \\
\text { yang ada di masing-masing kelas. }\end{array}$ \\
\hline
\end{tabular}




\begin{tabular}{|c|c|c|}
\hline 2. & MS/ guru kelas & $\begin{array}{l}\text { Bagaimana sistem pembelajaran pada DN dan MR di } \\
\text { kelas V ini: } \\
\text { Siswa yang mengalami hambatan berkemampuan } \\
\text { rendah ini pertama diberikan pembelajaran sama } \\
\text { dengan anak pada umumnya, namun setelah itu } \\
\text { secara individual diberikan bimbingan secara khusus } \\
\text { dan kalau tidak memungkinkan karena anak kurang } \\
\text { bisa mengikutinya maka anak di bawa ke ruang } \\
\text { khusus untuk diberikan bimbingan oleh guru khusus. } \\
\text { Apa bapak memiliki pemahaman tentang pendidikan } \\
\text { inklusi? } \\
\text { Awalnya saya tidak tahu pak setelah itu saya membaca } \\
\text { lalu dipraktikkan di madrasah ini. } \\
\text { Bagaimana sistem pembelajaran WR di kelas IV } \\
\text { Kalau saya mengajar WR setelah saya menjelaskan } \\
\text { secara klasikal lalu saya selalu memberikan perhatian } \\
\text { khusus terkadang saya bawa ke ruang belajar khusus. } \\
\text { Bagaimana sistem pembelajaran TL, DT, dan RR di } \\
\text { kelas III } \\
\text { Saya sudah tahu kemampuan TL DT dan RR, maka } \\
\text { saya selalu mengajarkan dengan pelan-pelan dan } \\
\text { menjelaskan sepaham mungkin dengan bahasa yang } \\
\text { jelas dan pelan. }\end{array}$ \\
\hline 3. & SM/ wakamad & $\begin{array}{l}\text { Bagaimana kurikulum yang diterapkan di madrasah } \\
\text { ini terkait dengan pendidikan inklusi bagi anak } \\
\text { berkemampuan rendah? } \\
\text { Kurikulum yang diterapkan di madrasah ini } \\
\text { menggunakan kurikulum terbaru yaitu kurikulum } \\
\text { 2013. Dalam pelaksanaannya terkait dengan anak } \\
\text { yang mengalami hambatan rendah kemampuannya } \\
\text { diterapkan dengan tetap menggunakan kurikulum } \\
\text { yang sama dengan anak lainnya namun dengan } \\
\text { memodifikasinya seperti dengan sistem pembelajaran } \\
\text { khusus melalui guru khusus bila anak mengalami } \\
\text { kesulitan namun jika masih mampu dengan } \\
\text { pembelajaran di kelas bersama guru kelas, maka } \\
\text { ketuntasan dilakukan di kelas bersama dengan yang } \\
\text { lain. }\end{array}$ \\
\hline
\end{tabular}




\begin{tabular}{|c|c|c|}
\hline 4. & $\mathrm{DN}$ dan $\mathrm{MR} /$ siswa & $\begin{array}{l}\text { Apakah kamu merasa senag belajar di madrasah ini? } \\
\text { Saya merasa senang pak karena kalau gak bisa saya } \\
\text { diajari dengan pelan-pelan di kelas atau dibawa ke } \\
\text { ruang belajar khusus saya selalu diajari dikelas } \\
\text { namun jika waktunya habis dan belum selesai maka } \\
\text { saya diteruskan belajarnya di ruang khusus. } \\
\text { Pelajaran apa yang kamu sering kurang paham jika diajar } \\
\text { guru di kelas? } \\
\text { Saya gak bisa kalau ngerjakan Matematika, saya } \\
\text { sering diajari di ruang khusus. }\end{array}$ \\
\hline 5. & WR/ siswa & $\begin{array}{l}\text { Apakah kamu bisa mengaji? } \\
\text { Saya belum bisa membaca al-Qur'an dengan baik } \\
\text { dan kalau pelajaran Qur'an Hadis saya selalu di ajari } \\
\text { sendiri oleh gurunya. } \\
\text { Selainkamu ada juga yang tidak bisa mengaji? } \\
\text { Hanya saya. } \\
\end{array}$ \\
\hline 6. & TL, DT, dan RR/ siswa & $\begin{array}{l}\text { Dalam belajar Bahasa Indonesia, apa yang kamu anggap } \\
\text { sulit? } \\
\text { Kalau pelajaran Bahasa Indonesia saya tidak suka } \\
\text { karena sulit dan selalu diajari secara khusus oleh } \\
\text { gurunya. } \\
\end{array}$ \\
\hline 7. & $\mathrm{RF} /$ Orang tua siswa & $\begin{array}{l}\text { Bagaimana menurut ibu kalau anak ibu dipindah } \\
\text { sekolahnya di sekolah khusus (SLB)? } \\
\text { Saya tidak mau karena anak saya normal, walau } \\
\text { sering tidak naik ya gak pa pa yang penting tetap di } \\
\text { madrasah ini. }\end{array}$ \\
\hline 8. & $\mathrm{MF} /$ teman siswa & $\begin{array}{l}\text { Apa kamu merasa suka dengan temanmu yang kurang } \\
\text { pandai? } \\
\text { Saya biasa saja dan sering main bersama. } \\
\text { Suka tidak dengan temanmu yang tadi? } \\
\quad \text { Ya suka pak. }\end{array}$ \\
\hline
\end{tabular}

\section{Pelaksanaan Madrasah Inklusi}

Berdasarkan data hasil penelitian bahwa di madrasah ini secara teknis telah memberikan layanan pendidikan inklusi bagi anak disabilitas. Terdapat 12 anak yang termasuk disabilitas yang dilayani di madrasah ini dengan diajar sesuai dengan kelasnya masing-masing. Jenis anak disabilitas yang dilayani di madrasah ini didasarkan pada identifikasi awal yaitu anak setelah diketahui selalu memiliki prestasi rendah dan sering tidak naik kelas lalu dilakukan tes IQ dan dari hasil tes 
itu menjadi dasar anak dikatakan disabilitas atau tidak, berdasarkan hasil tes IQ 12 anak yang disebut disabilitas tersebut memang rendah antara 70 sampai 85 masuk kategori lambat belajar. ${ }^{28}$ Awalnya orang tua disarankan untuk memindah anaknya ke SLB terdekat namun karena orang tua tidak mau dan dengan pertimbangan tertentu akhirnya diputuskan untuk diberikan pendidikan dengan cara yang khusus.

Karena melayani pendidikan bagi anak disabilitas bersama dengan anak normal di satu madrasah, maka dikatakan pendidikan inklusi. ${ }^{29}$ Dari sisi pelaksanaan pendidikan dinamakan inklusi namun dari sisi teknis, madrasah ini belum ada dokumen resmi sebagai madrasah inklusi. Hal ini disebabkan secara manajemen, madrasah itu berada di Kementrian Agama, sedang selama ini Kementerian Agama belum ada kebijakan terkait dengan pelaksanaan inklusi. Dengan kata lain Kementrian Agama belum membuka program layanan pendidikan inklusi. ${ }^{30}$

Dalam pelaksanaannya, madrasah berkonsultasi dengan Dinas Pendidikan Kecamatan sebagai penanggung jawab pelaksanaan sekolah inklusi. Dengan demikian madrasah ini dalam melakukan pelayanan inklusi didasarkan pada arahan dari Dinas Pendidikan Kecamatan. Dengan demikian dapat dikatakan sebagai rintisan madrasah inklusi walaupun belum bisa disebut madrasah inklusi.

Berdasarkan hasil wawancara dengan kepala madrasah dan wakil ketua bidang kurikulum, madrasah ini memiliki upaya yang serius untuk menjalankan program inklusi. Walaupun secara legal belum mendapatkan ijin operasional dari Dinas Pendidikan selaku pengelola program inklusi.

Dengan rintisan inklusi di madrasah ini, maka anak disabilitas akan mendapatkan peluang untuk bersekolah di dekat tempat tinggalnya bersama anak normal lainya. Dengan adanya inklusi di madrasah juga semakin menambah luasnya layanan pendidikan bagi anak disabilitas di daerah ini.

Dengan demikian, madrasah ini merupakan rintisan sebagai madrasah inklusi dan sekaligus menjadi model untuk dijadikan percontohan bagi madrasah yang lain untuk melaksanakan program inklusi di madrasahnya.

Madrasah sebagai lembaga pendidikan berbasis agama memiliki nilai lebih ketika mengelola inklusi karena madrasah mayoritas berada di daerah pedesaan,

28. Junanto S. Kusna, "Evaluasi Program Pembelajaran di PAUD Inklusi Dengan Model Context, Input, Process, and Product (CIPP), Journal of Disability Studies," hlm. 189.

29. O’Neil, J. Op Cit hlm. 7-11.

30. Sholikhah RM. Op Cit. hlm 64.

AL-BIDAYAH, Volume 10, Nomor 02, Desember $2018 \mid 165$ 
lebih menerima perbedaan siswa, dan memiliki muatan yang kuat dalam hal agama.

Guru-guru di madrasah ini juga memiliki antusias yang tinggi setelah memahami sistem pembelajaran inklusi dan keinginan membantu anak disabilitas di daerahnya.

\section{Model Layanan Pendidikan Inklusi di Madrasah}

Berdasarkan hasil penelitian didapatkan data bahwa pelaksanaan pembelajaran yang diterapkan di madrasah ini dapat dikatakan menggunakan model "pullout", yaitu model pembelajaran di kelas inklusi di mana anak disabilitas diajar dengan anak normal dalam satu kelas biasa dalam kelompok khusus, yaitu anak yang lambat dikelompokkan di depan dan pada saat-saat yang lain anak dibawa ke ruang sumber untuk belajar dengan guru pembimbing khusus. ${ }^{31}$ Hal ini didasarkan pada proses pembelajaran yang dilakukan oleh guru hasil observasi dan wawancara dengan guru dan siswa.

Ketika DN dan MR kelas V sedang belajar Matematika di kelas biasa dengan guru kelas, ternyata mereka mengalami kesulitan, setelah itu mereka menyelesaikan pelajaran Matematika dengan guru pembimbing kusus di ruang sumber belajar khusus sampai selesai, setelah itu kembali ke kelas biasa lagi. ${ }^{32}$

Pada saat WR kelas IV sedang belajar Qur'an Hadis pada kegiatan membaca dan menerjemahkan ayat, anak ini mengalami kesulitan dalam membaca lalu guru Qur'an Hadis membimbing di kelas itu dan dilanjutkan dengan dibimbing di ruang khusus agar WR belajar dengan tekun dan serius hingga selesai dan setelah itu masuk lagi di kelas biasa. ${ }^{33}$

TL, DT, dan RR kelas III pada saat belajar Bahasa Indonesia dalam tema mengarang ketiga anak ini mengalami kesulitan sehingga guru kelas lebih mendekati dan membantu anak untuk melakukan kegiatan mengarang. Dari proses belajar dengan guru di kelas ternyata ada hambatan, maka selanjutnya TL, DT, dan RR dibawa ke ruang sumber belajar dengan dilanjutkan guru pembimbing khusus $^{34}$. Walaupun secara teknis pelaksanaan tidak persis sama dengan pola "pullout" sebagaimana dalam teorinya namun peneliti memadukan apa yang

31. Direktorat Pendidikan Luar Biasa, Pedoman Penyelenggaraan Pendidikan Terpadu, hlm. 10.

32. Wawancara dengan guru kelas V di MI Ibtidaul Falah, 23 Agustus 2018.

33. Wawancara dengan guru kelas IV MI, 23 Agustus 2018

34. Wawancara dengan guru kelas III MI, 23 Agustus 2018

166 AL-BIDAYAH, Volume 10, Nomor 02, Desember 2018 
dilakukan di madrasah ini selanjutnya dianalisis dan disesuaikan dengan yang mendekati model pullout.

Model inklusi dapat dipilih sesuai dengan kondisi dan situasi madrasah. Jika anak disabilitas memiliki kemampuan yang baik atau hambatan yang dialami anak disabilitas tidak terlalu berat maka dapat menggunakan model inklusi penuh, dan jika tidak dapat dilakukan secara penuh dalam model inklusi ini dapat digunakan model cluster, pull out, atau kelas khusus, dan seterusnya. Model inklusi sesungguhnya harus sesuai dengan tingkat hambatan atau kemampuan anak.

Model inklusi di madrasah ini baik siswa DN, MR, WR, TL, DT, dan RR karena memiliki kemampuan yang rendah, maka model yang tepat adalah model "pullout" sehingga ketika ada hambatan dalam belajar, maka anak disabilitas akan ditangani oleh guru pembimbing khusus. ${ }^{35}$

Dengan model "pullout" ini, maka pembelajaran di madrasah inklusi mampu menuntaskan belajar bagi anak-anak disabilitas ${ }^{36}$. Secara teknis sebenarnya dalam pelaksanaan model inklusi bersifat tidak menetap sehingga dimungkinkan adanya kombinasi dalam pelaksanaan model inklusi ini.

Siswa DN, MR, WR, TL, DT, dan RR yang rata-rata memiliki kemampuan rendah dengan model "pullout" ternyata dapat meningkatkan kemampuan belajarnya. Dengan demikian penggunaan model ini bagi anak disabilitas tipe ini sangat tepat. ${ }^{37}$

Berdasarkan data hasil penelitian dapat dijelaskan bahwa pembelajaran yang dilakukan oleh guru-guru di MI Ibtidaul Falah Dawe, Kudus tergolong baik, walaupun guru di MI ini tidak memiliki latar keilmuan pendidikan khusus namun upaya untuk memahami pendidikan inklusi tergolong baik karena memiliki antusiasme yang tinggi untuk melaksanakan program inklusi di madrasah.

Terdapat nilai-nilai positif dalam pelaksanaan inklusi di MI bahwa dalam membimbing siswa lambat belajar, guru kelas selalu memberikan motivasi dan menanamkan nilai agama sebagaimana ungkapan, "jangan menyerah nak.. kamu bisa, belajarlah yang serius, "manjadda wa jada," jika kamu sungguh-sungguh pasti tercapai. Tuhan selalu menolong orang yang sungguh-sungguh, yang penting semangat ya!”.

35. Wawancara dengan guru kelas MI, 23 Agustus 2018

36. Ibid

37. Wawancara dengan siswa MI, 23 Agustus 2018

AL-BIDAYAH, Volume 10, Nomor 02, Desember $2018 \mid 167$ 
Ketepatan dalam menggunakan model akan menumbuhkan semangat dan motivasi belajar anak, sehingga rasa percaya diri dan harga diri anak disabilitas akan meningkat dengan baik. Peningkatan rasa percaya dan harga diri akan membangun rasa penerimaan diri yang lebih baik. Individu dengan penerimaan diri yang positif akan mampu menghayati apa yang ada dalam diri sebagai anugerah. ${ }^{38}$ Selanjutnya dengan penerimaan diri yang positif akan membantu anak disabilitas untuk tidak menolak keberadaannya tetapi sebaliknya akan lebih semangat hidup dan mengembangkan dirinya.

Di madrasah ini, guru kelas selalu memberikan motivasi dan penguatan pada siswa termasuk anak disabilitas sehingga penerimaan tentang kondisi yang dialami didasarkan pada rasa iman dan ketaqwaan ${ }^{39}$. Penerimaan diri bagi anak disabilitas merupakan hal penting karena dengan rasa penerimaan ini akan membangkitkan kemampuan dan potensi-potensi diri yang lain.

\section{SIMPULAN}

Hasil penelitian menunjukkan bahwa madrasah ibtidaul falah Dawe kudus secara praktis telah melaksanakan pembelajaran inklusi bagi siswa disabilitas lambat belajar atau ada juga tuna grahita yang diajar di kelas reguler bersama dengan anak normal sepanjang hari menggunakan kurikulum normal dengan bimbingan khusus.

Model pendidikan inklusi di madrasah ini menggunakan model "pullout" yaitu anak disabilitas belajar bersama temannya di kelas regular dalam kelompok khusus, dan dalam waktu-waktu tertentu ditarik dari kelas regular ke ruang sumber untuk belajar dengan guru pembimbing khusus. Hal ini didasarkan pada pertimbangan: 1) anak disabilitas di madrasah ini termasuk anak lambat belajar; 2) memiliki kesulitan dalam belajar pada mata pelajaran tertentu sehingga perlu penanganan pembimbing khusus; 3) pada pelajaran yang lainnya anak disabilitas ini masih bisa selesai pada kelas biasa.

38. Sari E.P. and Nuryoto S., "Penerimaan Diri Pada Lanjut Usia Ditinjau Dari Kematangan Emosi," Universitas Gadjah Mada Jurnal Psikologi (2002), hlm. 74.

39. Fahruddin H.S., Membentuk Moral Bimbingan Al-Qur'an (Jakarta: Bina Aksara, 1985), hlm. 57. 


\section{E. DAFTAR PUSTAKA}

Abdurrahman M. (2002) Landasan Pendidikan Inklusi dan Implikasinya dalam Penyelenggaraan LPTK, Makalah dalam Pelatihan Buku ajar bagi Dosen Jurusan PLB, Yogyakarta: 26 Agustus, 2002.

Al-Qur'an dan terjemah. (2008). Surabaya: Duta Ilmu

Amka. (2017). Implementasi Pendidikan Karakter Inklusi Bagi Anak Berkebutuhan Khusus Di Sekolah Reguler, Universitas Lambung Mangkurat Banjarmasin. Madrosatuna: Journal of Islamic Elementary School, 1 (1): 1-12.

Ancok Dj. \& Suroso FN. (1994). Psikologi Islami, Yogyakarta: Pustaka Pelajar.

An Efa Flagship. (2004). The Rights to Education for Persons with Disabilities: towards Inclusion, (Online), (http://unesdoc.unesco.org/education_for_all_ (efa_america)_inclusion.pdf, diakses 01 Nopember 2011.

Anjarsari AD. \& Sulthoni ME. (2015). Penyelenggaraan Pendidikan Inklusi Pada Jenjang SD, SMP, DAN SMA di Kabupaten Sidoarjo, Jurnal Pendidikan Luar Biasa FIP Universitas Negeri Malang 2015

Baker, ET. et. All. (1995) The Effects of Inclusion on Learning,Education Leadership Direktorat Pendidikan Luar Biasa, (2004). Pedoman Penyelenggaraan Pendidikan Terpadu (Jakarta: Dirjen Didakmen).

Fahruddin HS. (1985). Membentuk Moral Bimbingan Al-Qur'an, Jakarta: Bina Aksara.

Fitria R. (2012). E-JUPEKhu 1 (1) Januari 2012 http://ejournal.unp.ac.id/index.php/ jupekhu

Hasan bin Ali Al-Hijazy. (tt). Manhaj Tarbiyah Ibnu Qoyyim.

Haryono, Syaifudin A, dan Widiastuti S. (2015). Evaluasi Pendidikan Inklusif bagi Anak Berkebutuhan Khusus (ABK) di Provinsi Jawa Tengah. Jurnal Penelitian Pendidikan. Fakultas Ilmu Pendidikan. Universitas Negeri Semarang, 32 (2):119-129.

Junnanto S., Kusna NAS. 2018. Evaluasi Program Pembelajaran di PAUD Inklusi dengan Model Context, Input, Process, and Product (CIPP, INKLUSI: Journal of Disability Studies, Vol. V, No. 2, Juli-Desember 2018. IAIN Surakarta. 
Mukaffa Z. Taufik, \& Huda MN. (2017). Pengembangan Model Madrasah Inklusif (Studi Atas Kesiapan Dan Model Pengembangan Kurikulum Madrasah Inklusif Mi Al-Hidayah, Margorejo Surabaya, Edukasia: Jurnal Penelitian Pendidikan Islam. UIN Sunan Ampel Surabaya. 12 (1):1

O’Neil J.(1994/1995). Can inclusion work.A Conversation With James Kauffman and Mara Sapon-Shevin. Educational Leadership. 52(4) 7-11.

Peraturan Menteri Pendidikan Nasional Nomor 70 Tahun 2009 tentang pendidikan inklusif bagi peserta didik yang memiliki kelainan dan memiliki potensi kecerdasan dan/ atau bakat istimewa.

Pratiwi JC. (2015). Sekolah Inklusi Untuk Anak Berkebutuhan Khusus: Tanggapan Terhadap Tantangan Kedepannya. Prosiding Seminar Nasional Pendidikan "Meretas Sukses Publikasi Ilmiah Bidang Pendidikan Jurnal Bereputasi", Kerja sama Program Studi S-3 Ilmu Pendidikan, Program Studi S-2 Pendidikan Luar Biasa Universitas Sebelas Maret Surakarta dan ISPI Wilayah Jawa Tengah, Surakarta, 21 November 2015.

Rencana Strategis Depdiknas 2010-2014. Jakarta: Departemen Pendidikan Nasional. Sari EP. \& Nuryoto S.(2002). Penerimaan Diri Pada Lanjut Usia Ditinjau Dari Kematangan Emosi, Jurnal Psikologi, Universitas Gadjah Mada 2002, NO. (2): 73 - 88, ISSN: $0215-8884$.

Sholikhah RM. (2016). Pendidikan Inklusif di Kementerian Agama (Studi di Madrasah Ibtidaiyah Ma,arif Giriloyo 2 dan Madrasah Ibtidaiyah YAPPI Balong), tesis. tt.,Pascasarjana Universitas Islam Negeri Yogyakarta.

Shopyatun AR. \& Rasido I. (2013). Pengembangan Bahan AjarAnak Berkebutuhankhusus untuk Pendidikan Inklusi bagi Mahasiswa Program Studi PG/PAUD FKIP Universitas Tadulako, Tri Sentra Jurnal Ilmu Pendidikan 2 (4)

Soma S. \& Hajaruddin, (2000). Menanggulangi Remaja Kriminal Islam Sebagai lternatif, Bandung: Nuansa.

Sue Stubbs. (2002). Pendidikan Inklusif: Ketika Hanya Ada Sedikit Sumber. Judul asli: Inclusif Education: Where There Are Few Resources. Dialihbahsakan oleh: Susi Septaviana. Bandung: Jurusan Pendidikan Luar Biasa UPI.

Sugiyono. (2010), Metode Penelitian Pendidikan, Bandung, Alfabeta. 
Surat Edaran Dirjen Dikdasmen Nomor 380/C.C6/MN/2003 tanggal 20 Januari 2003 tentang pendidikan inklusif

Skjorten, M. (2003). Menuju Inklusi dan Pengayaan, (Online),(http://www.idpeurope.org/indonesia/buku-inklusi-14k, diakses 02 Nopember 2011.

Sopan-Shevin M. (1995). Why Gifted students Belong in the Inclusive Schools, Educational Leadership.

Stoub D \& Peck C.a (1995) What are the outcame for non disable Student?, educational leadership.

Stubbs, Sue. (2002). Pendidikan Inklusif (Ketika Hanya Ada Sedikit Sumber). Bandung: UPI.

Undang-undang Nomor 20 Tahun 2003 Tentang Sistem Pendidikan Nasional. Jakarta: Departemen Pendidikan Nasional.

UNESCO. (1994). Penyataan Salamanca dan Kerangka Aksi

Mengenai Pendidikan Kebutuhan Khusus, (Online), (http://www.idp-europe.org/ indonesia/docs/SALAMANCA_indo.pdf, diakses 02 Nopember 2011.

https://www.kemdikbud.go.id/main/blog/2017/02/sekolah-inklusi-danpembangunan-slb-dukung-pendidikan-inklusi 
